\title{
İSLÂM KELÂMI AÇISINDAN MÛCİZE KERÂMET İLIŞKİSİ
}

The Relationship Between Miracle and Karamat In Terms Of Islamic Kalam Veysi ÜNVERDí

Doç. Dr. Mardin Artuklu Üniversitesi, İslâmi İlimler Fakültesi

Assoc. Prof. Mardin Artuklu University, Theology of Islamic Science

veysinet@hotmail.com

ORCID ID: 0000-0002-8364-4412

DOI: $10.34085 /$ buifd. 746600

Öz

Mûcize ve kerâmet mevzusu, kelâm ilminin nübüvvet meseleleri arasında yer alır. Klasik kelâm ilminde mûcize nübüvvetin dayanağı olarak kabul edilir. Kerâmet ise velî kişilere nispet edilen hârikulâde hadiselerdir. Allah'ın elçilerini teyit etmek üzere yarattığı hadiseler, genellikle tabiat kanunlarının bir süreliğine askıya alınması şeklinde gerçekleşir. Kelâm okulları mûcizeyi nübüvvetin delili olarak değerlendirmişken kerâmet üzerinde ihtilaf etmişlerdir. Mu'tezile, mûcizenin temel işlevinin nübüvvetin ispatına yönelik olduğunu kabul etmiş ve çoğunluk, peygamber dişındaki kimselerden hârikulâde bir hadisenin zuhur etmesinin nübüvvet müessesesini zedeleyeceğini savunmuştur. Ehl-i Sünnet ise mûcizenin peygambere özgü olduğunu vurgulamış ve -bazı istisnalar olmakla beraber- kerâmetin vukuunu imkân dâhilinde kabul etmiştir. Bu çerçevede makalede mûcizenin mahiyeti, hakikati, şartları, peygamberlerin doğruluğuna delâleti, kerâmetin hakikati, imkânı, mûcize ile ilişkisi ve doğruluk kıstası olarak ele alınıp alınamayacağı hususları incelenmiştir.

Anahtar Kelimeler: Mûcize, Keramet, Velî, Peygamber, Nübüvvet.

\section{Abstract}

The subject of miracle and karamat is among the prophethood (nubuwwah) issues of kalam. In classical kalam, miracle is considered the basis of prophethood. Karamat is a wonderful event that is attributed to his devout servant. The events that Allah has created to confirm his messengers usually take place in the form of the suspension of the law of nature for a while. While Kalam schools considered miracle as proof of prophethood, they disagreed on karamat. Mu'tezile acknowledged that the main function of miracle was to prove the prophethood, and the majority argued that the occurrence of an incident that occurred beyond anyone other than the prophet would damage the prophethood establishment. Ehl-i Sunnah emphasized that the miracle was unique to the prophet and accepted the occurrence of the miracle, although there are some exceptions. In this context, in the article, the nature of the miracle, the proof of the truth of the prophets, fact of karamat and its relationship with miracle whether it can be considered as a criterion of truth are examined.

Keywords: Miracle, Karamet, Saint, Prophet, Nubuwwah.

\section{Giriș}

Kelâm ilminin temel mevzularından birisi olan nübüvvet meselesi farklı yönleriyle kelâm okulları tarafından ele alınıp değerlendirilmiştir. Kelâm âlimleri ilâhi buyrukların insanlara ulaştırılması ve Allah ile insan arasındaki iletişimin sağlanabilmesi için Allah'ın insanlara peygamberler gönderdiğini ifade etmişlerdir. Peygamberlerin davetine muhatap olan toplumlar da peygamberlerden risâletlerinin ispatını talep etmişlerdir. Bu durum bütün peygamberler için geçerlidir. Bu noktada nübüvvetin ispatını sağlayan kanıt mûcize olmuştur. Böylece Allah mûcize ile peygamberleri desteklemiş ve doğrulamıştır. Bunun neticesinde insanlar ikna 
edilmiş ve peygamberler tasdik edilmiştir. Mûcizeler, karşılık bulabilmesi için toplumda revaçta olan hususlar çerçevesinde gerçekleşmiştir. Sözgelimi sihrin yaygin olduğu bir dönemde Hz. Musa'ya asâ mûcizesi; tıp alanında ileri olunan bir dönemde Hz. İsa'ya körlüğü ve alaca hastalığını iyileştirme mûcizesi; edebiyatın/belağatin revaçta olduğu devirde $\mathrm{Hz}$. Peygamber'e Kur'an mûcizesi verilmiştir.

Mûcizeler peygamberlere özgü olup ancak nübüvvetle ilişkilendirilebilir. Fakat bazı tasavvufî eserlerde mûcize ile kerâmet arasında sıkı ilişki kurulmuş ve kerâmete, velî (sâlih) ve evliya kavramlarına çok farklı anlamlar yüklenmiştir. Hatta bazı şahıslara Allah katında özel bir mertebe (abdal, ğavs, kutub, nücebâ vb.) atfedilmiş ve söz konusu şahısların elinde mûcizelerin dahi ortaya çıkabileceği iddia edilmiştir. Bu düşünceyi savunanlara göre nübüvvet, zahiri itibariyle sona ermiş olmakla birlikte bâtını, yani velayet ve tasarrufta bulunma yönüyle devam etmektedir. Çünkü Hz. Muhammed'in (sav) ümmetinden olan velîlerin ruhları, O'nun velayetinin tasarrufunu taşımaktadırlar; bu sebeple onlar kıyamete kadar tasarruf hakkına sahiptirler. Yani nübüvvet kapısı kapalı olmakla beraber velayet kapısı açıktır. Velînin doğruluğunun işareti zahirde Hz. Peygamber'e tabi olmasıdır; her ikisi de tasarruf yetkisini aynı kaynaktan almaktadır. Velîler Hz. Muhammed'e (sav) tabi olarak insanları hak yola davet etmişlerdir. ${ }^{1}$ Bunun yanında mûcize ile ilgili farklı yaklaşımlar da mevcuttur. Sözgelimi mûcizenin, peygamberlerin tebliğ ettikleri esasların sıhhat ölçütü olamayacağı iddia edilmiştir. ${ }^{2}$ Bazı âlimlerse velî ve kerâmet kavramlarına yükledikleri yeni anlamlarla nübüvvetin dolaylı bir şekilde devam ettiğini, kerâmetin de Hz. Peygamber'in mûcizesi olduğunu iddia etmiştir. Bu sebeple mûcizenin mahiyeti, hakikati, şartları, peygamberlerin doğruluğuna delâleti, kerâmetin hakikati, imkânı, mûcize ile ilişkisi ve doğruluk kıstası olarak ele alınıp alınamayacağı konularının kelâmî açıdan değerlendirilmesi gerekmektedir. Mûcize ve kerâmete ilişkin yapılan çalışmalarda ağırlıklı olarak ya mûcize konusu ya da kerâmet konusu tek başına ele alınmıştır. Bu çalışmada ise mûcize ve kerâmet meselesi birlikte detaylı bir şekilde ele alınacak ve mûcize ve kerâmetin doğruluk kıstası olarak ele alınıp alınamayacağı hususu ayrı bir başlık altında incelenecektir.

1. Mûcize

1.1. Mûcizenin Tanımı

Mûcize "bir şeye güç yetirememek" anlamındaki "acz" kökünden türemiştir. Terim olarak mûcize, "peygamberlik iddia eden kimsenin, kendi doğruluğunu kanttlamak için inkârcılara meydan okuduğu sırada, başkalarının benzerini yapamayacakları -Allah tarafından yaratılanhârikulâde bir şeyi ortaya koyması" şeklinde tanımlanır. ${ }^{3}$ Tanımdan da anlaşılacağı üzere mûcize Allah'ın fiilidir ve peygamberlere özgüdür. Kur'an'da "acz" kökü fiil ve sıfat olarak birçok ayette yer almakla birlikte mûcize şeklinde kullanılmamıştır. Kur'an'da peygamberlerin Allah tarafından gönderildiğini ispatlayan hârikulâde hadiseler, genellikle "ayet" (ayat) kelimesiyle ifade edilmiştir. Hz. Sâlih'in dişi devesi, ${ }^{4} \mathrm{~Hz}$. Musa'nın asâsı ve parıltılı eli, ${ }^{5} \mathrm{~Hz}$. İsa'nın gösterdiği tabiatüstü olaylar ${ }^{6}$ ve inkârcıların peygamberlerden mûcize talepleri ${ }^{7}$

\footnotetext{
1 Yusuf Şevki Yavuz, "İslam İnancında Kutsiyet, Velayet ve Kerâmet İnancına İtikadi Mezheplerin Bakışı”, İslam Düşünce Geleneğinde Kutsiyet Velayet Kerâmet, ed. Yusuf Şevki Yavuz (İstanbul: Kuramer Yayınları, 2017), 124, 136.

2 Muhammed Hamidullah, "Mûcize, Kerâmet, İstidrac", ter. Zahit Aksu, Hikmet Yurdu 3 (2009): 84, 93.

${ }^{3}$ Bk. M. F. Abdülbâkî, el-Mu'cemu'l-Mufehres li elfâzi'l-Kur'ani'l-Kerîm, (Kâhire: Dâru'l-Hadîs, 2007), "acz" mad.

${ }^{4} \mathrm{~A}^{\prime}$ râf $7 / 73$

${ }^{5}$ A'râf 7/106-108; Kasas 28/ 31-32, 35.

${ }^{6}$ Âl-i İmrân 3/49-50.
} 
genellikle ayet kelimesiyle anlatılmıştır. Bunun yanında beyyine, burhan, sultan, hak ve furkan kelimeleri de zaman zaman mûcize anlamında kullanılmıştır. ${ }^{8}$ Hadislerde de peygamberliği ispat için öne sürülen deliller genellikle ayet kelimesiyle ifade edilmiştir. Mûcize teriminin kelâm ilminde kullanımı ise X. yüzyıldan itibarendir. ${ }^{9}$

\subsection{Mûcizenin Şartları/Özellikleri ve Kısımları}

Mûcizenin peygamberin doğruluğunu ispat edebilmesi için bazı koşulları haiz olması elzemdir. Kelâm âlimleri mûcizenin şartlarına/özelliklerine değinmişlerdir. Bunları maddeler halinde şu şekilde sıralayabiliriz:

1. Mûcize -beşer kudretinin üzerinde- olağanüstü bir şekilde zuhur eder. Dolayısıyla peygamberlik iddiasında bulunan kimse "güneşin doğudan doğup batıdan batacağını" söylerse, bu sözü, onun doğruluğuna kanit teşkil etmez. Zira adette olan -herkesin bildiği- bir şeyi bildiren veya insanların yapabileceği bir şeyi ortaya koyan kimsenin fiili peygamberlik delili olamaz. ${ }^{10}$

2. Mûcize ilâhi bir fiil olduğu için ancak Allah'ın izni ile vuku bulabilir. Peygamberler tek başlarına bir mûcize ortaya koyamadıkları için insanların bütün mûcize taleplerine olumlu yanıt verememişler ve mûcizenin ancak Allah'ın izniyle gerçekleşebileceğini ifade etmişlerdir. Allah'ın izni ile gerçekleşen mûcize de peygamberlik iddiasında bulunan kimsenin doğruluğuna delâlet eder. ${ }^{11}$

3. Mûcize, peygamberin yaşadığ dönemde yaygın/revaçta olan hususlar (tarihi zemin ve sosyo-kültürel yapı paralelinde) çerçevesinde gerçekleşir. Örneğin sihrin yaygın olduğu dönemde Hz. Musa'ya "asâ" mûcizesi; ${ }^{12}$ tıbbın geliştiği bir dönemde Hz. İsa'ya "ölüleri diriltme", ${ }^{13}$ "kör ve alaca hastalarını iyileştirme"14 mûcizesi; şiir ve edebiyatın (hitabet, belağat, fesahat) revaçta olduğu bir devirde Hz. Peygamber'e "Kur'an" mûcizesi verilmiştir. Böylelikle mûcizeler, toplum içerisinde etkili olmuş ve karşıllk bulmuştur.

Mûcizenin sosyo-kültürel yapı paralelinde gerçekleşmesi, insanların peygamberleri tasdik etmesini sağlamakta ve insanlar ikna edilmektedir. Bu noktada mûcizenin tasdike yöneltme ve ikna yönü önemli bir husus olarak karşımıza çıkmaktadır. Bu noktada mucizenin, stratejik bir yöntem olarak peygamberleri tasdik etmenin aynı zamanda ilâhi mesajın iletildiği toplumu ikna etmenin bir aracı olduğu söylenebilir. Bu açıdan mûcize, ilâhi bir lütuf olmaktadır. Aslında kitleleri etkilemenin en güçlü yolu, onların duyusal algılarıyla etkileşime geçmektir. Olağanüstü olaylar da toplumların her zaman ilgisini çekmiş ve onları etkilemiştir. ${ }^{15}$

4. Mûcizede bir benzerini yapabilme/getirme konusunda inkârcılara yönelik bir meydan okuma (tehaddî) söz konusudur. Mûcize, bu meydan okumadan hemen sonra vuku bulur. Peygamber, mûcize ile inkârcılara meydan okumadan önce peygamberlik iddiasını dile getirmiştir. Meydan okuma söz konusu olmaksızın peygamberde görülen hârikulâde hadiseler,

\footnotetext{
7 İsrâ 17/59.

${ }^{8}$ Bk. Kasas 28/32; Bakara 2/53, 87, 92, 253; Yâsîn 36/46, Nisâ 47155; Hud 11/96; Yunus 10/76-77.

9 Bekir Topaloğlu\&İlyas Çelebi, Kelâm Terimleri Sözlüğü (İstanbul: İsam Yayınları, 2013), 219; Halil İbrahim Bulut, "Mûcize" (İstanbul: TDV Yayınları, 2005), 30/350.

${ }^{10}$ Kâdî Abdülcebbâr, Şerhu'l-Usuli'l-Hamse, tah. Abdülkerim Osman (Kahire: 1996), 569.

${ }^{11}$ Bk. Kâdî Abdülcebbâr, Şerh, 569-572.

12 Tâhâ 17-20.

13 Âl-i İmrân 3/49.

14 Âl-i İmrân 3/49.

${ }^{15}$ Hüseyin Maraz, "Mûcizenin Teolojik Açıdan Delil Oluşu ve İlahi Yasalarla İlişkisi”, İ.Ü. İlahiyat Fakültesi Dergisi 8/2 (2017): 313-314.
} 
terim anlamıla mûcize olarak adlandırılmaz. Mûcize güç yetirilemeyen bir tarzda vuku bulduğu için, onun bir benzeri meydana getirilemez ve bu sebeple insanlar mûcize karşısında aciz kalırlar. ${ }^{16}$ Peygamberlik iddiası ve bir meydan okuma söz konusu olmaksızın nübüvvetten önce vuku bulan hârikulâde hadiseler ise mûcize olarak değil de daha sonra gelecek olan peygamberi ve çevresini onun peygamberliğine hazırlama anlamına gelen "irhâsât" şeklinde değerlendirilmiştir. Genel olarak kelâmcılar irhâsât ve nübüvvet sonrası tehaddî söz konusu olmaksızın gerçekleşen olağanüstü olayları, peygamberin doğruluğunu ortaya koyan bir delil olarak değil de onu destekleyen bir karine olarak değerlendirmişlerdir. ${ }^{17}$

5. Mûcize peygamberin iddiasına uygun olmalı, yani beyan ettiği şekilde vuku bulmalıdır. ${ }^{18}$

Öte yandan kelâm âlimleri mûcizeyi, genel olarak aklî ve hissî olmak üzere iki gruba ayırmışlardır. Bunun yanı sıra bazen haberî mûcizeler de ayrı başlık altında ele alınmıştır. Bunları aşağıda maddeler halinde inceleyelim:

1. Hissî Mûcize: İnsanların duyularına hitap eden bu tür mûcizeler, tabiatla alakalı olmaları hasebiyle kevnî mûcizeler olarak da adlandırılır. Hissî mûcizeler tabiat kanunlarını değiştiren ilâhi fiillerdir. Hz. Sâlih'in dişi devesi, ${ }^{19} \mathrm{~Hz}$. Musa'nın asâsının yılana dönüşmesi, elinin parıltılı bir ışık vermesi, ${ }^{20}$ asâsı ile kayadan su çıarması ${ }^{21}$ kavminin bulutla gölgelendirilmesi, gökten kudret helvası ve bıldırcın etinin indirilmesi, ${ }^{22} \mathrm{~Hz}$. İsa'nın kuş şekline çevirdiği çamuru canlandırması, ölüleri diriltmesi ve anadan doğma körleri ve alaca hastalığına yakalananları iyileştirmesi, ${ }^{23}$ Firavun ve ordusunun denizde boğulmasi ${ }^{24}$ hissî mûcizelere birer örnek olarak verilebilir. Hissî mûcizeler sadece peygamberin hayatta olduğu dönemi ve mekânı kapsar. Sonraki nesillerin hissî mûcizeleri tasdik etmesi, ancak nass yoluyla mümkündür. ${ }^{25}$

Hz. Peygamber'e, kendisine ikram edilen kızartılmış koyun etinin zehirli olduğunu haber vermesi, parmaklarının arasından su fışkırması, az bir yemekle birçok kişiyi doyurması, üzerine çıktığı kütüğün onun müfarakatı ile inlemesi gibi daha birçok farklı mûcize isnat edilmektedir. Her ne kadar kaynaklarda bunlar, âhâd haber olarak nakledilmişse de Cüveynî'nin (ö. 478/1085) ifade ettiği gibi hepsi birleştirildiğinde söz konusu hârikulâde hadiselerin peygamberden sâdır olması, söz konusu haberleri mütevâtir hale getirdiği söylenebilir. ${ }^{26} \mathrm{Bu}$ konudaki haberlerin, bazı gerekçelerle tamamen reddedilmesi isabetli bir yaklaşım değildir. Her ne kadar rasyonalizmin ve pozitivizmin tesiri ile bu gibi hârikulâde hadiseler, anormal

\footnotetext{
${ }_{16}$ Bk. Kâdî Abdülcebbâr, Şerh, 569-572; el-Muğnî fî Ebvâbi't-Tevhîd ve'l-Adl (Kahire: 1962-65,) 15/199; Fahruddîn er-Râzî, Kitâbu'l-Erbaîn, neş. A. Hicâzî es-Sekâ (Kahire: Mektebetü'l-Ezher, 1986), 2/202.

${ }^{17}$ Bk. Teftâzânî, Şerhu'l-Akâid, ter. Süleyman Uludağ (İstanbul: Dergah Yayınları, 1999), 317 (14. dipnot); Adil Bebek, “Kelam Literatürü Işığında Mûcize ve Hz. Muhammed'e Nispet Edilen Hissî Mûcizelerin Değerlendirilmesi”, M.Ü. İlahiyat Fakültesi Dergisi 18 (2000): 122-123.

${ }^{18}$ Kâdî Abdülcebbâr, Şerh, 570.

${ }^{19}$ A'râf 7/73; Hûd 11/64; Şu'arâ 26/155.

${ }^{20}$ A'râf 7/107-108, 117-122; Tâhâ 20/19-22; 67-70.

${ }^{21}$ Bakara 2/60; A'râf 7/160

22 Bakara 2/57; A'râf 7/160; Tâhâ 20/80

23 Âl-i İmrân 3/49; Mâide 5/110.

${ }^{24}$ Bakara 2/50; A'râf 7/136-137; Yunus 10/90; İsrâ 17/103-104.

${ }^{25}$ Bk. Halil İbrahim Bulut, Nübüvvetin İspatında Mûcize (Ankara: Araştırma Yayınları, 2016), 36.

${ }^{26}$ Cüveynî, Kitâbü'l-İrşâd, tah. M. Yusuf Musa-Abdulmun'im Abdulhamid (Mısır, 1950), 353-354.
} 
karşılansa da Müslümanların çoğunluğu Kur'an'da da benzeri durumlar nakledildiği gerekçesi ile zikredilen örnekleri hârikulâde hadiseler olarak değerlendirmişlerdir. ${ }^{27}$

2. Aklî Mûcize: Mânevî veya bilgi mûcizesi olarak da adlandırılan aklî mûcize, insanların akıl ve idraklerine hitap eder; hârikulâde olması itibariyle de ancak düşünme yoluyla kavranabilir. Aklî mûcize, hissî mûcize gibi belirli zaman ve mekâna hasredilemez, kıyamete kadar geçerliliğini ve etkisini korur. Peygamberlerin emin, doğru sözlü, güzel ahlak ve şefkat sahibi olmaları, iyiliği emredip kötülükten nehyetmeleri, tebliğ ettikleri ilâhi mesajı bizzat uygulayıp insanlara model olmaları, öğretilerinin erdemli bir toplum için vazgeçilmez prensipler mesabesinde olması, dünya ve ahiret saadetine ulaşmanın yegâne yollarını göstermeleri, tebliğ ettikleri vahiy ürünü nassın lafız ve muhteva bakımından mûcizevî yönlerinin bulunması aklî mûcizeye örnek olarak verilebilir.

$\mathrm{Bu}$ noktada şunu da vurgulamak gerekir ki Hz. Peygamber'in tebliğ ettiği ilahî mesaj evrenseldir. Bu durum, onun nübüvvetini ispatlayan mûcizenin de her dönemde hiç tükenmeyen bir mûcize olmasını gerektirmiştir. Bu bağlamda ona, Kur'an verilmiştir. Kur'an en büyük aklî mûcizedir. Diğer peygamberlere ise hissî mûcize verilmiştir; bu mûcizeler o dönemdeki insanlara yöneliktir ve o dönemle sınırlıdır. Esasında Allah, her peygambere kendi döneminin şartlarına uygun ve o dönemde revaçta olan hususlara paralel mûcizeler vermiştir. Nübüvvetin ispatı, insanların henüz olgunluk çağına ulaşmadığı dönemde hissî mûcizeler yoluyla gerçekleşmişken, insanlığın olgunluk çağına ulaştığı ve aklî gelişim açısından büyük mesafe kat ettiği Hz. Peygamber döneminde, insan aklına ve bilgisine hitap eden Kur'an ile gerçekleştirilmiştir. Nitekim şiir ve edebiyatın revaçta olduğu bir asırda, Hz. Peygamber'e, sihir veya tıp sahasına ilişkin bir mûcizenin verilmesi, istenilen amacın gerçekleşmesine engel olacağı gibi bu tür bir mûcize toplumun idrakine de hitap etmeyecektir. Dolayısıyla İslâm dininin tebliğ sürecinde mûcize bağlamında duyusal alandan aklî tefekkür aşamasına geçiş yapılmıştır. Neticede Hz. Peygamber'e verilen mûcize etkisini kendisinden sonra da devam ettirmiştir.

3. Haberî Mûcize: Peygamberlerin vahye dayanarak verdikleri gaybî haberlere haberî mûcizeler denir. Peygamberlerin âsi toplulukların başlarına gelecek hususlarla ilgili önceden haber verdikleri hususların aynen vuku bulması, Hz. İsa'nın, kavminin evlerinde neler yiyip ve biriktirdiklerini kendilerine bildirmesi, ${ }^{28} \mathrm{~Hz}$. Peygamber'in Bizanslılar'ın İranlılar'1 savaşta mağlup edeceğini ${ }^{29}$ ve Kisrâ'nın saltanatının yıkılacağını haber vermesi haberî mûcizeye birer misal olarak verilebilir. ${ }^{30}$ Peygamberlerin söz konusu bildirimleri, herhangi bir araciya müracaat etmeksizin sadece Allah'tan aldıkları vahye dayanarak gerçekleşmiştir. Bunun yanında peygamberlerin önceki kavimlerin başına gelen olayları ve bu olaylara ilişkin şahısların konuşmalarını tafsilatlı bir şekilde nakletmeleri de geçmişe dönük bir haberî mûcize niteliği taşımaktadır. Kur'an'da anlatılan kıssalar bunun en güzel örneğidir. ${ }^{31}$ Gaybî haberlerin ayrı bir mûcize kategorisinde değerlendirilemeyeceği ve bu doğrultuda haberî mûcizelerin peygamberlerin nübüvvetini ispat edemeyeceği yaklaşımı ise kanaatimizce isabetli değildir.

\footnotetext{
${ }^{27}$ Hayati Aydın, "İslam İnançları Açısından Mûcize, Kerâmet, Sihir ve İstidrac Kavramları Üzerine Bir Değerlendirme", S. Ü. İlahiyat Fakültesi Dergisi, 17/32 (2015): 111-112; bk. Nesefî, Tebsıratü'l-Edille fì Usûli'd-Dîn, tah. H. Atay-Ş. Ali Düzgün (Ankara: D.İ.B Yay., 2004), 2/107.

28 Âl-i İmrân 3/49.

${ }^{29}$ Rûm 30/1-4.

30 Bulut, "Mûcize", 30/350-351.

31 Teftâzânî, Şerhu'l-Mekâsıd, tah. Abdurrahman Umeyre (Beyrut: 1989), 5/35.
} 
Nitekim Kâdî Abdülcebbâr'ın (ö. 415/1025) da isabetle belirttiği üzere Kur'an'ın Ebû Cehil, Ebû Leheb ile ilgili verdiği gaybî haberler, Hz. Peygamber'in nübüvvetini ispat eder niteliktedir. ${ }^{32}$

Diğer taraftan mûcizeler gaye yönüyle de sınıflandırılmıştır. Bu bağlamda yapılan mûcize tanımlamalarını üç grupta inceleyebiliriz:

1. Yardım Mûcizeleri: Bu tür mûcizeler tehaddî, peygamberlik iddiası ve mûcizenin diğer temel kriterlerine sahip değildir. Müslümanların bazı ihtiyaçlarını gidermeye yönelik gerçekleşen yardım mûcizeleri, nübüvvetin ispatı için bir delil niteliği taşımaz. Hz. Musa'nın İsrailoğlulları için kayadan su çıkarması, acıktıkları vakit gökten kudret helvası ve bıldırcın indirmesi, ${ }^{33}$ sıcak havadan bunaldıklarında gölgelenmeleri için bulut getirmesi, ${ }^{34}$ Bedir savaşında meleklerin Müslümanlara yardım etmesi ${ }^{35}$ yardım mûcizelerine birer misal olarak verilebilir. ${ }^{36}$

2. Helâk Mûcizeleri: Bu tür mûcizeler küfürde ısrar eden ve peygamberlere karşı gelen inkârcılara yönelik gerçekleşen olağanüstü olaylardır. Helâk mûcizeleri genellikle fırtına, yıldırım, korkunç bir çığlık/ses, tufan, deprem ve benzeri tabii âfetler şeklinde vuku bulmuştur. ${ }^{37}$ Akıl ve idrake hitap eden helâk mûcizelerinin sonraki nesiller için ibret verici bir yönü de bulunmaktadır.

3. Hidâyet/İrşad Mûcizeleri: Bu tür mûcizeler kelâm ilminde zikredilen mûcize şartlarının tamamın haizdir. Meydan okuma ile birlikte vuku bulan ve nübüvveti ispat eden hidayet mûcizesi, temelde inkârciların peygamberleri tasdik etmesi ve ikna edilmesine yöneliktir. Bu doğrultuda gerçekleşen hidâyet mûcizesi peygamberi inkâr eden insanların huzurunda ve onları acze düşürecek şekilde vuku bulur. Peygamberler, hidâyet mûcizesi olmaksızın muhataplarını dinen sorumlu tutmazlar. Kur'an'da zikredilen Hz. Sâlih'in devesi, ${ }^{38} \mathrm{~Hz}$.

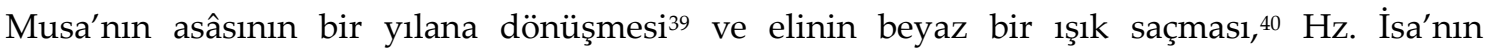
çamurdan yaptığı kuşu canlandırması, doğuştan körlüğü olanları ve alaca hastalarını iyileştirmesi, ölüleri diriltmesi, ${ }^{41} \mathrm{~Hz}$. Muhammed'in (sav) Kur'an mûcizesi hidayet mûcizesine birer örnektir. ${ }^{42}$

\subsection{Mûcizenin Peygamberin Doğruluğuna Delâleti}

Öncelikle şunu vurgulamak gerekir ki peygamberin sahip olduğu vasıflar, ona iman edilmesi için kâfidir. Peygamberin ahlakı, tutum ve davranışları, verdiği yargılar, üyesi olduğu ailesi, kendisinden nefret ettirecek herhangi bir davranışın ondan sâdır olmaması gibi hususlar ise onun doğru olduğunu ortaya koymaktadır. Önceki peygamberin kendisinden sonra gelecek peygambere ilişkin bildirimi de daha sonra gelen peygamberin doğruluğuna delildir. Nitekim Hz. Peygamber'in peygamberliği de önceki kutsal kitaplarda bildirilmişs3 ve bu durum onun

\footnotetext{
32 Bk. Kâdî Abdülcebbâr, Tesbîtü Delâilin'n-Nübüvve, tah. Abdülkerim Osman (Beyrut, tsz.), 36-37.

33 Bakara 2/57.

${ }^{34}$ A'râf 7/160.

35 Âl-i İmrân 3/123-125.

36 Bk. H. İbrahim Bulut, "Sünnî Gelenekte Mûcize Kavramı ve Hz. Salih'in Deve Mûcizesi”, Dinbilimleri Akademik Araştırma Dergisi 4/3 (2004): 140-141.

${ }^{37}$ Bk. Ankebût 29/40; A'râf 7/59-64, 80-84, 78; Yunus 10/71-73; Hûd 11/42-43, 65-67; Hicr 15/83; Bulut, “Mûcize”, 30/351.

${ }^{38}$ A'râf 7/73; Hûd 11/64; Kamer 54/27.

39 A'râf 7/107, 117-118; Tâhâ 20/19-21, 65-69.

40 A'râf 7/108; Tâhâ 20/22.

41 Âl-i İmrân 3/49; Mâide 5/110.

42 Bk. Bulut, "Sünnî Gelenekte Mûcize Kavramı ve Hz. Salih'in Deve Mûcizesi”, 142-143; Râzî, Kitâbu'l-Erbaîn, $2 / 199$.

43 A'râf 7/157; Saf 61/6.
} 
doğruluğunu ispatlamada delil kabul edilmiştir. Bütün bu hususların haricinde peygamberlerin doğruluğunu ortaya koyan asıl ve en önemli delil mûcizedir. Mûcizeye şahitlik eden insanlar, mûcizenin kendi elinde zuhur ettiği kimsenin Allah tarafından gönderilen bir elçi olduğuna kanaat getirirler. ${ }^{44}$

Mûcize, peygamberlerin toplum tarafından kabul görüp onaylanması, onların tebliğ ettiği ilâhi mesajlara tabi olunması ve insanların dinen mükellef kılınabilmesi için elzemdir. Mûcize ile temelde peygamberliğin bilinmesi ve peygamberin doğru olduğunun ortaya konulması amaçlanır. Dolayısıyla nübüvvetin ispatı için mûcize zorunludur. ${ }^{45}$ Kâdî Abdülcebbâr da Allah'ın, görevlendirdiği elçisini mûcize ile desteklediğini ve bazı şartları taşıyan mûcizenin de peygamberin doğruluğunu ortaya koyduğunu ifade etmiştir. ${ }^{46}$ Kâdî Abdülcebbâr'ın zikrettiği söz konusu şartlar ise şunlardır:

1. Mûcize, ilâhi bir fiil olmalıdır.

2. Mûcize peygamberlik iddiasının arkasından vuku bulmalıdır.

3. Mûcize peygamberin -meydan okuduğu- iddiasına uygun olmalıdır.

4. Mûcize hârikulâde olmalıdır. ${ }^{47}$

Ebû Hâşim el-Cübbâ̂̂'ye (ö. 321/933) göre ise mûcize sadece nübüvvete delâlet eder ve bu sebeple sadece gerçek peygamberin elinde zuhur eder. Ona göre mûcizenin, peygamberin doğruluğuna delalet ettiği iddia edilirse, bu durumda tüm doğru kimselerin elinde zuhur etmesi gerekir. ${ }^{48}$

XX. yüzyılın önemli âlimlerinden birisi olan Muhammed Hamidullah mûcize ile peygamberin doğruluğu arasındaki ilişki hakkında farklı bir görüş öne sürmüştür. Ona göre mûcize ile peygamberin tebliğinin sıhhati arasında (onun doğruluğunu ispatlayıcı) bir ilişki yoktur. Yani mûcize, maddî sebebi bilinmeksizin veya hiçbir maddî sebebe dayanmaksızın vuku bulmuş olsa da mûcize ile peygamberin öğrettiklerinin doğruluğu arasında bir ilişki yoktur ve mûcize peygamberin mesajının doğruluğunu kanitlamaz. ${ }^{49}$ Kanaatimizce şayet mûcize, peygamberin tebliğ ettiği ilâhi mesajin doğruluğuna delil teşkil etmiyorsa, peygamberin doğruluğuna da delil olmayacaktır. Belirtilen iddiaya katılmamız söz konusu değildir. Çünkü mûcizenin en temel fonksiyonlarından birisi, peygamberin doğruluğunun ispatlanmasıdır. Peygamber Allah tarafından mûcize ile teyit edilmişse, bazı şartları haiz olan bu mûcize, hiç şüphesiz peygamberin ilettiği mesajın da doğru olduğunu ortaya koyar.

\section{Kerâmet}

\subsection{Kerâmetin Tanımı}

Kerâmet sâlih/velî kulların ellerinde zuhur eden hârikulâde hadise şeklinde tanımlanır. Kerâmet mûcize gibi tabiat kanunlarıyla açıklanamayan olağanüstü bir olay olmakla beraber meydana geliş şekliyle mûcizeden ayrılır. Mûcize sadece peygamberden, kerâmet ise velî kimselerden sâdır olur. Peygamber nübüvvetin ispatı için mûcizeye yönelir ve inkârcılara mûcize ile meydan okur; velî kimse ise herhangi bir iddiada bulunmadığı gibi hiç kimseye de

\footnotetext{
${ }^{44}$ Bk. Kâdî Abdulcebbâr, Muğnî, 15/274; Fahruddîn er-Râzî, el-Muhassal, çev. Hüseyin Atay (Ankara: A.Ü. İlahiyat Fakültesi Yay., tsz.), 207-208; Râgıb el-İsfahânî, el-İ'tikâdât (Beyrut: 1988), 128-129; Abdullatif Harpûtî, Tenkîhu'l-Kelam fiAkâid-i Ehli'l-İslam, çev. İ. Özdemir-F. Karaman (Elazığ: TDV Yayınları, 2000), 229.

${ }^{45}$ Bk. Râzî, Kitâbu'l-Erbaîn, 2/199-205.

${ }^{46}$ Kâdî Abdülcebbâr, Şerh, 569.

${ }^{47}$ Kâdî Abdülcebbâr, Şerh, 569-571.

${ }^{48}$ Kâdî Abdülcebbâr, Muğnî, 15/219.

${ }^{49}$ Muhammed Hamidullah, "Mûcize, Kerâmet, İstidrac", 84, 93.
} 
meydan okumaz. Keza mûcize gösteren kimsenin peygamber olduğunun şuurunda olması, fevkalade olaylar göstermeye yönelmesi ve bunların sonuçlarını kesin telakki etmesi gerektiği halde kerâmet gösteren velîde zikredilen hususlar söz konusu değildir. ${ }^{50}$

İslâm akaidinde "Velîlerin kerâmetleri haktır." şeklinde ifade edilen velayet ve kerâmetin bir inanç konusu olarak yer aldığı ilk kaynak, "Ebû Hanife'ye nispet edilen (ö. 150/767) el-Fıkhu'lEkber adlı risaledir. Burada kerâmet itikadî bir mesele gibi görülmüşse de söz konusu esere ilişkin Ebû Hanife'ye ait olmayan bazı ilavelerin yapılmış olabileceğine dair yaklaşımların bulunması, kerâmet anlayışının onun döneminde ortaya çıkmış olması ihtimalini zayıflatmaktadır. Kerâmete ilkin terim anlamını yükleyen ve onu itikadî bir mesele haline getirenlerin Sünnî sufîler olduğu söylenmiştir. Kerâmete ilişkin tartışmalar, h. 3. asrın sonlarında yoğun bir şekilde yapılmış ve İbrahim b. Ethem (ö. 195/782), Rabia el-Adeviyye (ö. 185/801), Fudayl b. İyaz (ö. 187/803) gibi ilk sufîlerin ardından teşekkül eden Sünnî tasavvuf ekolleri, kerâmetin velîlerce gösterilen hârikulâde bir olay olduğunu belirtmiş ve bu münakaşalar neticesinde konu İslâm akaidine dâhil edilmiştir." 51

Diğer taraftan sufîler kerâmeti kevnî/hissî ve manevî olarak ikiye ayırmış ve daha çok manevî kerâmete değer vermişlerdir. Onlara göre tayy-1 mekân, kışın yaz meyvelerine nail olma, ateşte yanmama gibi hârikulâde haller kevnî kerâmet olup pek fazla önemli değildir; hatta bu tür kerâmetler bazen olumsuz hadiselere de neden olabilir. Asıl kerâmet, dinin buyruklarını yerine getirmek, kötü söz ve davranışları terk edip iyi ahlak sahibi olmak, istikamet üzere olmak, nefse hâkim olup gayret göstererek ilim ve irfan sahibi kâmil bir insan olmaya gayret etmek anlamındaki mânevî kerâmettir. ${ }^{52}$

\subsection{Kerâmetin İmkânı}

Mânevî kerâmet Mu'tezilî ve Sünnî kelâmcılar tarafından kabul edilmiştir. Kevnî keramet konusunda ise farklı görüşler ileri sürülmüştür. Kevnî kerameti Mu'tezile, mûcize ile karışabileceği ve nübüvvet müessesesini yıpratacağı gerekçesiyle reddetmiştir. ${ }^{53}$ Sufîler ve Ehl-i Sünnet'in çoğunluğuna göre ise kevnî keramet mümkündür. Onlar bu konuda bazı nasslar1 ${ }^{54}$ delil kabul etmişlerdir. Esasında Ehl-i Sünnet âlimlerinin çoğunluğu kerâmeti, velî kullar elinde gerçekleşen hârikulâde bir hadise olarak tanımlamış ve bu hadiselerin yaratılmasını aklî düzlemden hareketle imkân dâhilinde görmüşlerdir. Aslında akıl, kerâmeti tabiat kanunlarının normal işleyişi bağlamında olanaksız görebilir. Ama Allah, tabiatın işleyişine yönelik ortaya koyduğu kuralları dilediği zaman da değiştirebilir. Dolayısıyla da kerâmetin vukuu mümkün kabul edilebilir. ${ }^{55}$

Cüveynî kerâmetin mümkün olduğunu şu ifadelerle açıklar: Hârikulâde olan şeyler, Allah'ın kudreti dâhilindedir. Aklın bir şeyi kötü görmesi, o şeyin gerçekleşmesine mani

\footnotetext{
${ }^{50}$ Bekir Topaloğlu\&İlyas Çelebi, Kelâm Terimleri Sözlü̆̆̈̈, 182; bk. Nesefî, Tebsıra, 2/108; Teftâzânî, Şerhu'l-Akâid, 314; Seyyid Sâbık, Akâidü'l-İslâmiyye, Beyrut 1406, 214.

51 Yusuf Şevki Yavuz, "Kerâmet", TDV İslâm Ansiklopedisi (Ankara: TDV Yay., 2002), 25/268; bk. Ali el-Kârî, Şerhu Kitabi'l-Fikhi'l-Ekber (Beyrut, 1984), 113; Hâris el-Muhâsibî, Risaletü'l-Müsterşidin, neş. Abdülfettah Ebu Gudde (Halep, 1964), 87, 92-93; Ahmed b. Hanbel, Kitâbu'z-Zühd, tah. M. Celal Şeref (İskenderiyye: 1984), 180.

52 Süleyman Uludă̆, "Kerâmet”, TDV İslâm Ansiklopedisi (Ankara: TDV Yayınları, 2002), 25/267; Hakîm et-Tirmizî, Nevâdiru'l-Usul, tah. M. Abdülkadir Ata (Beyrut, 1992), 1/293-294.

${ }^{53}$ Kâdî Abdülcebbâr, Muğnî, 15/242-243.

${ }^{54}$ Bk. Kehf 18/10-26, 74-80; Neml 27/40; Âl-i İmrân 3/28.

${ }_{55}$ Bk. Cüveynî, Kitâbu'l-İrşâd, 316; Nesefî, Tebsıra, 2/107; Gazzâlî, el-ikttisâd fi'l-I'tikâd (Beyrut: Daru'l-Kütübi'l-İlmiyye, 1983), 125; Râzî, Kitâbu'l-Erbaîn, 2/199; Cürcânî, Şerhu'l-Mevâklf, 8/314-315; Teftâzânî, Şerhu'l-Akâid, 314; bk. Murat Serdar, “Ehl-i Sünnet İnancında Kerâmetin İmkân ve Vukû'u Problemi”, Bilimname 14/2 (2010): 43.
} 
değildir. Kerâmetin vukuu mûcizeye zarar vermez. Mûcize risâletle ilişkilidir ve sözle tasdik yerine geçtiği için önem arz eder. ${ }^{56}$ Cürcânî ise kerâmetin imkânını şöyle açıklamıştır: Mümkünler Allah'ın kudretine dayalıdır ve O'nun kudreti açısından imkânsız değildir. Allah'ın fiillerinde bir amacın bulunma zaruriyeti de yoktur. Bu açıdan kerâmet de imkân dâhilindedir. ${ }^{57}$ Netice olarak Ehl-i Sünnet, aklî düzlemden hareketle kerâmetin mümkün olduğunu savunmuştur.

Kerâmetin imkânsız olması Allah'ın kerâmeti yaratma kudretinin bulunmadığı ya da insanın lütfa layık olmamasına bağlanabilir. Fakat söz konusu ihtimallerinin bir geçerliliği yoktur. Nasslardan hareketle Allah'ın her şeye kadîr olduğu ve sâlih kulların da ilâhi lütfa mazhar olacağı bilinebilir. ${ }^{58}$ Esasında mûcize ve kerâmet gibi iki olağanüstü olayın kabulü, âlem ve Tanrı ilişkisini "yaratan-yaratılan" şeklinde kabul etmekle mümkündür, denilebilir. Zira âlemin Allah tarafından yaratıldığ 1 ve belirli kanunlarla donatıldığı kabul edildiğinde yaratıcının âleme müdahalesi de mümkün olur. İslâm geleneğinde kabul görmüş muhdes, mahlûk ve mümkin âlem anlayışı, İslâm âlimlerini "âlemde her an ilâhi müdahalenin mümkün olduğu" sonucuna götürür. Mûcize ve kerâmetin imkânını bu hakikate pekâlâ dayandırabiliriz.

\subsection{Kerâmet İnancına İlişkin Yaklaşımlar}

Ehl-i Sünnet âlimlerinin çoğunluğu nasslardan ve aklî delillerden hareketle kerâmetin mümkün olduğunu savunmuşlardır. ${ }^{99}$ Onlara göre Allah'ın bir hadiseyi âdetullaha muvafık veya aykırı bir şekilde yaratması mümkündür; hârikulâde bir hadisenin velînin elinde zuhur etmesinin mûcizeye herhangi bir tesiri yoktur ve gerçekleşen bu hadisenin mûcize ile karışması söz konusu değildir. Bunun yanında velînin elinde zuhur eden kerâmetin, onun tâbi olduğu peygamberin doğruluğunu ispat eden bir delil mesabesinde olduğu, bu yönüyle kerâmetin mûcizeyi desteklediği de savunulmuştur. ${ }^{60}$ Bazı Sünnî âlimler ise sâlih kimselerin elinde zuhur eden kerâmetin, peygamberliği kıyamete kadar devam eden son peygamber Hz. Muhammed'in (sav) mûcizesi gibi görülebileceğini ifade etmişlerdir. Böylece kul, yaptığı iyi ameller (itaatin) karşıllı̆ında, olağanüstü ilâhi bir fiili müşahede etmiş olur. ${ }^{61}$ Sufîler ise kerâmetin vukuunu mümkün görmüş ve kerâmeti Allah'a boyun eğen ve O'na yaklaşmaya çalışan velî kullara Allah'ın bir ikramı ve lütfu olarak değerlendirmişlerdir. Onlara göre ilâhi bir ikram olarak kabul edilen kerâmete nail olan bir velî, bu hadisenin bir mekr, istidrâc ve ibtilâ olmasından çekinir ve imtihan edilmek istendiğini düşünerek korkuya kapılır. Kerâmete mazhar olan velî, Allah'ın lütfuna mazhar olduğu için O'na hamdeder ve daha çok bağlanır. ${ }^{62}$

Kerâmetin mümkün olduğunu ve vuku bulduğunu savunanlar, bazı deliller öne sürmüşlerdir. Bunların bazısını şöyle maddeleştirebiliriz:

\footnotetext{
${ }^{56}$ Cüveynî, Kitâbü'l-İrşâd, 319.

${ }^{57}$ Cürcânî, Şerhu'l-Mevâkıf, 8/314.

${ }^{58}$ Râzî, Mefâtihu'l-Gayb (Beyrut: Daru'l-Kütübi'l-İlmiyye, 2000), 21/ 76.

${ }^{59}$ Ahmed b. Hanbel, el-Akîde, tah. A. İzzeddin es-Seyrevan (Dimeşk, 1408), 125- 126; İbn Hazm, el-Fisal fi'l-Milel ve'l-Ehva ve'n-Nihal (Beyrut: 1317), 5/9-11; Bağdâdî, Usûlu'd-Din, 175; Şehristânî, el-Milel ve'n-Nihal, neş. M. Seyyid Kilânî (Beyrut, 1986), 1/84-85; Cürcânî, Şerhu'l-Mevâkıf, neş. M. Ömer Dimyati (Beyrut, 1998), 8/314; Yavuz, "Kerâmet”, 25/268.

${ }^{60}$ Nesefî, Tebsıra, 2/107-110; Sâbûnî, el-Bidâye fî̀ Usûli'd-Dîn, ter. Bekir Topaloğlu (İstanbul: İFAV, 2018), 113; Âmidî, Gâyetu'l-Merâm fi İlmi'l-Kelâm, tah. H. Mahmud Abdüllatif (Kahire, 1971), 335; bk. H. İbrahim Bulut, "Hârikulâde Olması Açısından Kerâmet ve Mûcize İle İlişkisi", S.Ü İlahiyat Fakültesi Dergisi 3 (2001): 333-337.

${ }^{61}$ Gazzâlî, el-İktisâd, 98; Sâbûnî, el-Bidâye, 112-113; bk. Yavuz, "Kerâmet", 25/ 268.

62 Uludağ, "Kerâmet", 25/ 265; bk. Nesefî, Tebsıra, 2/109.
} 
1. Hz. Meryem kıssası kerâmetin gerçekliği konusunda öne sürülen en önemli delillerden birisidir. Kur'an'da anlatılan hadiseye göre Hz. Zekeriyyâ, Hz. Meryem'in mabette bulunan odasına her gittiğinde onun yanında birtakım rızıklar görmekte, bu rızıkların nereden geldiğini sorunca da Hz. Meryem, bunların kendisine Allah tarafından verildiğini ifade etmekteydi. ${ }^{63} \mathrm{~Hz}$. Meryem'e devamlı olarak böyle bir rızkın verilmesi olağanüstü bir hadisedir. Bu olağanüstü olay, Hz. Zekeriyyâ'nın bir mûcizesi olarak görülemez. Çünkü onun söz konusu rızıkların nereden geldiğini sorması ve dolayısıyla bunlardan haberinin olmaması, bu olağanüstü hadisenin onun mûcizesi olmadığını gösterir. Hz. Meryem bir peygamber olmadığı için onun yaşadığ1 söz konusu hârikulâde olay, mûcize olarak da değerlendirilemez. Bu durumda $\mathrm{Hz}$. Meryem'e ikram edilen rızıklar ancak kerâmet olarak açıklanabilir. ${ }^{64}$ Ayrıca Hz. Meryem'in, Hz. İsa' yı babasız dünyaya getirmesi, ${ }^{65}$ insan suretinde de olsa melekleri müşahede etmesi, ${ }^{66}$ doğum zamanı yaklaşınca kış mevsimi olmasına rağmen kuru hurma ağacının ona yaş hurma vermesi, ${ }^{67}$ onun yaşadığ 1 diğer olağanüstü hadiselerdir.

2. Kerâmetin gerçekliğini savunanların öne sürdüğü diğer önemli bir delil ise Ashab-1 Kehf kıssasıdır. ${ }^{68}$ Kıssaya göre iman ettikleri için aranan ve takip edilen bazı Müslümanlar bir mağaraya sığınmış ve orada üç yüz küsur yıl köpekleriyle beraber her türlü musibet ve hastalıktan korunarak hayatta kalmışlardır. Normal şartlar altında onların bu kadar uzun bir süre uykuda kalmaları ve hayatlarını sürdürebilmeleri mümkün değildir. Çünkü bu durum âdete aykırıdır. Bu hadiseyi yaşayanlar peygamber olmadıklarına göre, söz konusu hadise kerâmet olarak açılanabilir. Bu hadise, o dönemdeki peygamberin bir mûcizesi olarak görülemez. Bir olayın mûcize olarak adlandırılabilmesi için bunu ortaya koyan peygamberin ve bir benzerini meydana getirmeleri için kendilerine meydan okuduğu insanların, bu hadiseyi müşahede etmeleri ve dolayısıyla bu süre zarfında uyumadan yaşamlarını sürdürmeleri gerekir. Kur'an'da hadisenin bu kısmına değinilmemiş, bu sebeple olay kerâmet olarak nitelendirilmiştir. ${ }^{69}$

3. Kerâmetin imkânını savunanlar Hz. Süleyman'ın yanında bulunan ve adı zikredilmeyen bir kişinin, Sebe melikesi Belkıs'ın tahtını uzak bir mesafeden göz açıp kapayıncaya kadar kısa bir sürede getirmesi, ${ }^{70} \mathrm{~Hz}$. Ömer'in, Medine'de cuma hutbesini okurken düşmanların bulunduğu yerden uzaklaşması için Nihâvend'de bulunan ordu komutanı Sâriye'ye ve ordusuna "Ya Sâriye dağa çekiliniz, dağa" şeklinde hitap etmesi ve aralarında çok uzak bir mesafe olmasına rağmen Sâriye'nin bunu işitmesi, ${ }^{71}$ kuraklık yılında Hz. Ömer'in mektubu sayesinde Nil nehrinin suyunun artması örneklerini de ileri sürmüşlerdir. Bunun dışında

\footnotetext{
63 Âl-i İmrân 3/37.

${ }^{64}$ Bk. Cüveynî, Kitâbü'l-İrşâd, 320; Râzî, Kitâbu'l-Erbaîn, 2/202; Cürcânî, Şerhu'l-Mevâkuf, 8/314-315; Teftâzânî, Şerhu'lAkâid, 315.

${ }^{65}$ Meryem 19/16-23.

${ }_{66}$ Âl-i İmrân 3/45, 19.

${ }^{67}$ Meryem 19/25.

${ }^{68}$ Kehf 18/9-26.

${ }^{69}$ Cüveynî, Kitâbü'l-İrşâd, 320; Râzî, Mefâtihu'l-Gayb, 21/73; Kitâbu'l-Erbaîn, 2/203; Cürcânî, Şerhu'l-Mevâkuf, 8/315; bk. Yavuz, "İslam İnancında Kutsiyet, Velayet ve Kerâmet İnancına İtikadi Mezheplerin Bakışı", 128-129.

${ }^{70}$ Nesefî, Tebsıra, 2/107; Teftâzânî, Şerhu'l-Akâid, 315.

${ }^{71}$ Nesefî, Tebsıra, 2/107; Teftâzânî, Şerhu'l-Akâid, 315; Kuşeyrî, er-Risâletü'l-Kuşeyrîyye (Beyrut, 2001), 380.
} 
tâbiînden ve daha sonraki nesiller içerisinde yer alan velîlerden aktarılan bazı kerametlerden de bahsedilmiştir.72

Kerâmetin gerçekliğini savunanlar, kerâmete yönelik tenkitlere şu şekilde yanit vermişlerdir: Kur'an'da anlatılan hârikulâde olayların velî kimselerin elinde gerçekleşmiş olması, bu hadiselerin benzerlerinin de vuku bulabileceğine delildir. Kerâmet âdetullaha aykırı olsa da bazen kerâmetin vukuu mümkündür; fakat velîler insanları âdetullaha aykırı davranmaya teşvik etmez. Âdetullaha aykırı olması bağlamında mûcize ve kerâmet eşdeğerdir. Kerâmetin âdetullaha aykırı olması, onun gerçekleşmesine mani değildir. Ayrıca kerâmete ilişkin mevzu rivayetlerin olması, söz konusu hadiselerin Kur'an ve sahih hadislerle sabit oluşunu ortadan kaldırmaz. Kerâmetin ağırlıklı olarak sahabeden sonraki dönemlerde görülmesi pek tabiidir, zira sahabe Hz. Peygamber'in mûcizelerini müşahede etmiştir. Daha sonraki nesillerin, imanlarını kuvvetlendirmek için kerâmete ihtiyaç duymaları, kerâmetin artmasına neden olmuştur. Bunun yanında kerâmet, mûcizeyi risâletin kanıtı olmaktan çıkarmadı̆̆ı gibi nübüvveti de teyit eder, zira kerâmet sahibi velînin peygambere tâbi olması da bunun delilidir. Diğer taraftan Hz. Meryem ve Ashab-ı Kehf kıssaları mûcize ile ilişkilendirilemez. Çünkü söz konusu hadiseler peygamberlik iddiası ve tehaddî gibi mûcizenin şartlarını haiz değildirler. ${ }^{73}$

Bazı âlimlerse kerâmetin gerçekliğini inkâr etmişlerdir. Genel olarak Mu'tezilî âlimler, İbn Ebû Zeyd el-Kayrevânî (ö. 310/922), Ebû Abdullah el-Halîmî (403/1012), Ebû İshak el-İsferâyînî (ö. 418/1027) gibi bazı Sünnî kelâmcılar bu düşüncenin savunucularındandır. Mu'tezilî kelâmcılar, olağanüstü olayların velî şahıslar elinde gerçekleşmesinin mûcize ile karışabileceği ve bu sebeple de nübüvvet müessesesinin yıpranacağı gerekçesiyle kevnî kerâmetin vukuunu imkânsız görmüşlerdir. ${ }^{74}$

Mu'tezilî ekole göre Kur'an'da anlatılan ve bazı sâlih kimselere atfedilen hadiseler, kerâmet olmayıp o dönemlerde yaşayan peygamberlerin mûcizeleridir. ${ }^{75}$ Esasında Kur'an'da anlatılan Ashab-ı Kehf dışındaki diğer olaylar, bir peygamberle alakası bulunan sâlih kullardan zuhur etmiştir. Belkıs'ın tahtının nakledilmesi Hz. Süleyman ile, Hz. Meryem'in yaşadığı hârikulâde hadiseler, Hz. Zekeriyyâ ve Hz. İsa ile açıklanmıştır. Mûcizeler nebinin isteği üzerine zuhur edebilir, fakat mûcizenin peygamber tarafından mutlaka bilinmesi elzemdir. Hz. Zekeriyyâ'nın, Hz. Meryem'in yanındaki yiyeceklerin nereden geldiğini ona sorması, kendi mûcizesini bilmemesi anlamına geleceği için söz konusu hadise, Hz. Zekeriyyâ'nın mûcizesi olarak görülemez. Bu hadise Hz. İsa'nın mûcizesi olarak da kabul edilemez. Çünkü o, zikredilen hadise çerçevesinde bir nübüvvet iddiasında bulunmamıştır. Bu noktada yapılacak zorlama te'viller, mûcizeye ilişkin soru işaretlerinin artmasına sebebiyet verecektir. Aslında mûcize ile hedeflenen peygamberlik iddiasında bulunan kimsenin doğruluğunu ortaya koymaktır ve böylece insanları ikna etmektir. Hâlbuki Cebrail'in gelmesini, Hz. Meryem'in mûcizevî şekilde gerçekleşen hamileliği ve benzeri hadiseleri diğer şahıslar müşahede etmemiştir. Dolayısıyla

\footnotetext{
72 Sâbûnî, el-Bidâye, 112-113; Yavuz, "İslam İnancında Kutsiyet Velayet ve Kerâmet İnancına İtikadi Mezheplerin Bakışı”, 126.

${ }^{73}$ Bk. Cürcânî, Şerhu'l-Mevâklf, 8/315; Beyâzîzâde Ahmed Efendi, İşârâtü'l-Meram, neş. Yusuf Abdürrezzak (Kahire: Mektebetü'l-Halebî, 1368), 338; Yavuz, "Kerâmet", 25/267.

${ }^{74}$ Ahmed b. Hanbel, el-Akîde, 125-126; Bağdâdî, Usûlu'd-Dîn, 175; Şehristânî, el-Milel ve'n-Nihal, 1/84-85; Nesefî, Tebsira, 2/107; Cüveynî, Kitâbü'l-İrşâd, 317; Cürcânî, Şerhu'l-Mevâkıf, 8/314; İbn Hazm, el-Fisal fi'l-Milel, 5/9-11.

${ }^{75}$ Kâdî Abdülcebbâr, Muğnî, 15/216.
} 
sâlih kullara atfedilen hârikulâde hadiseleri aynı dönemde yaşayan peygamberin mûcizesi olarak takdim etmek çok da isabetli bir yaklaşım değildir. ${ }^{76}$

Kerâmetin vukuunu imkânsız görenlerin itirazlarını ise kısaca şu şekilde maddeleştirebiliriz:

1. Kerâmet hârikulâde tarzda gerçekleşen bir hadise olduğu için bunun velî kulun elinde zuhur etmesi söz konusu değildir. Hârikulâde hadiseler nübüvvetin ispatı için elzemdir ve peygamberlere özgüdür. Peygamberin dışında velî veya herhangi bir kimsenin hârikulâde bir hadiseyi gerçekleştirdiğini iddia etmek, Mu'tezilî âlimlerin ifadesine göre mûcizeyi nübüvvetin delili olmaktan çıkaracaktır. Bu durumda ise bazı sûfîlerin iddia ettiği gibi peygamber ile velî aynı mertebeye getirilmiş olacaktır. ${ }^{77}$

2. Yaşadığımız âlemdeki -mûcizeler dışındaki- hadiseler, tamamen sünnetullah çerçevesinde vuku bulur. Kur'an'da, insanların, Allah'ın tabiatı yaratıp devam ettirmek ve sosyal hayatı düzenlemek üzere koyduğu kanunlar çerçevesinde çalışmaktan başka bir çaresinin olmadığına dikkat çekilir. ${ }^{78} \mathrm{~Hz}$. Peygamber ve sahabe de bu doğrultuda hayatlarını sürdürmüşlerdir. Kerâmet şayet velî kullarda görülen bir hadise olsaydı, en fazla sahabe ve tâbiîn döneminde görülmesi gerekirdi. Fakat onların ellerinde kerâmetin vuku bulduğunu bizlere gösteren mütevâtir bir haber yoktur. ${ }^{79}$ Velî kimselere atfedilen kerâmetlere ilişkin rivayetler, âhâd haberlerdir. Söz konusu rivayetlerin râvileri de genellikle bilgisizlerdir. Kerâmete ilişkin haberlerin çoğunluğunun İslâm'ın hak din olduğunu ortaya koymak ve insanların İslâm dininin emir ve yasaklarına uymalarını sağlamak için iyi niyetle üretildiği söylenebilir. Maalesef bu yolla istenilen amaca ulaşıldığı söylenemez. Zira meşhur olmak ve menfaat elde etmek için farklı dinlerin din adamlarına da benzer olağanüstü hadiseler nispet edilmiştir. Keza Hallâc-ı Mansûr'a nispet edilen kerâmetler de insanları aldatmaya yöneliktir. Esasında kerâmetin vuku bulduğunu bildiren bir kanıt mevcut değildir. Velî olmak için olağanüstü bir hadisenin ortaya konulması gerektiğini bildiren bir nass da yoktur. Buna rağmen kerâmetler ağırlıklı olarak müridler tarafından üretilerek velî şahıslara atfedilmiş ve bunun neticesinde de kerâmet anlayışı Müslümanları gerçek hayattan uzaklaştırıp farklı beklentilere sürüklemiştir. ${ }^{80}$

3. Kur'an'da gaybın Allah'tan ve O'nun bilgilendirdiği peygamberlerden başkası tarafından bilinemeyeceğinin açıklanması ${ }^{81}$, dinde kerâmetin meydana gelişini sağladığı kabul edilen nafile ibadetlerden daha çok farz ibadetlere kıymet verilmesi ve kerâmete ilişkin örneklerin III. (IX.) yüzyıldan itibaren ortaya çıkması, kerâmet inancının dinî bir dayanağının olmadığını ortaya koymaktadır. Kur'an'da beyan edilen ve kerâmet olduğu iddia edilen hadiseler ise genellikle bir peygamberin etrafında cereyan etmektedir. Bu sebeple söz konusu hadiseleri, ilgili peygamberin doğruluğunu teyit eden mûcizeler gibi görmek gereklidir..$^{82}$

4. Kâdî Abdülcebbâr, Ebû Ali el-Cübbâî (ö. 303/916) ve Ebû Hâşim el-Cübbâî'ye (ö. 321/933) göre kerâmetle kastedilen mûcize gibi olağanüstü bir olaysa, bunun vukuu söz konusu değildir.

\footnotetext{
76 Bulut, "Hârikulâde Olması Açısından Kerâmet ve Mûcize ile İlişkisi", 339-340; bk. Râzî, Kitâbu'l-Erbaîn, 2/202; Teftâzânî, Şerhu'l-Mekâsıd, 5/74.

77 Bk. Kâdî Abdülcebbâr, Muğnî̀, 15/217-259.

78 Sünnetullaha ilişkin ayetler hakkında bk. Âl-i İmrân 3/137; İsrâ 17/77; Ahzâb 33/38, 62; Fâtır 35/43; Mü'min 40/85; Fetih $48 / 23$.

79 Teftâzânî, Şerhu'l-Akâid, 314.

80 Kâdî Abdülcebbâr, Muğnî, 15/217-218, 226, 241, 270-279; Râzî, Kitâbu'l-Erbaîn, 2/199-205; Ferîd Vecdî, el-İslam fi Asri'lİlm (Kahire, 1932) 2/226; Yavuz, "Kerâmet", 25/268-269.

${ }^{81} \mathrm{Neml}$ 27/65; En'am 6/59.

82 Bağdâdî, Usûlu'd-Dîn, 175; Sâbûnî, el-Bidâye, 112-113; Ferîd Vecdî, el-íslam, 2/233-234; Yavuz, “Kerâmet”, 25/268-269.
} 
Çünkü olağanüstü hadiseler, sadece peygamberin elinde vuku bulabilir. Şayet kastedilen olağanüstü bir fiil değilse, bu tür fiilleri her insan gerçekleştirebilir. Aslında nübüvvetin ispatı zorunludur, bu ise ancak mûcize ile mümkündür. Sâlih kimselerin ise Allah katındaki konumlarının bilinmesi zorunlu değildir. Diğer taraftan küçük bir canlıyı diriltmenin kerâmet, ölüyü diriltmenin ise mûcize olduğu da söylenemez. Zira küçük görülen hârikulâde hadiseler de çok önemlidir, sünnetullaha aykırılık yönünden her ikisi de eşdeğerdir. Dolayısıyla söz konusu hadiseler kerâmet olarak nitelendirilemez. Bunun yanında kerâmete ilişkin rivayetler de kesin bir bilgi ihtiva etmemektedir. Şayet sâlih kullardan hârikulâde hadiseler vuku bulmuş olsaydı, öncelikle kerâmetin ashab ve tâbiînden sâdır olması gerekirdi. Fakat onlardan kerâmetin zuhur ettiğine dair mütevâtir bir haber mevcut değildir. Netice olarak kevnî kerâmetin kullardan sâdır olması söz konusu değildir. ${ }^{83}$ Bu noktada şunu da vurgulamak gerekir ki Mu'tezile açısından mûcize, nübüvvetin kanıtı olduğu için bu tür olağanüstü hadiselerin velî kulların ellerinde zuhur ettiğinin kabul edilmesi, onların peygamber mertebesine yükseltilmesi veya diğer insanlarca böyle konumlandırılması neticesi pekâlâ doğurabilir. Onlar, nübüvvetin imamlar vasıtasıyla devam ettiğini ispatlamaya çalışan Şia'ya karşı bu tezi savunmuş ve peygamberliğin Hz. Muhammed (sav) ile sona erdiğini açıkça vurgulamışlardır..$^{84}$

Kerâmete ilişkin yaklaşımlar ve bu konudaki delillerden de anlaşıldığı üzere nasslarda kerâmete inanmanın gerekliliğine değinilmemiştir. Kerâmet kavramı III. (IX) yüzyıldan sonra oluşan menakıbın da etkisiyle süreç içerisinde bir itikadî prensip haline evrilmiştir. Allah'ın sâlih kullarını gözetip onlara dünyada müjdeler verdiğini bildiren nasslar dikkate alındığında, onların dualarının karşılık bulması, ilâhi lütuf sayesinde uygun taleplerinin karşılanması, sadık rüyalar görülmesi ve istikamet üzere yaşamaya muvaffak olunması tarzında gerçekleşecek kerâmetlerin varlığı pekâlâ kabul edilebilir. Fakat insanı gerçek hayattan uzaklaştıran ve ancak bir peygamberde görülebilen hârikulâde hadiseler gibi velînin tabiat üzerinde tasarruf etmesine dayanan kerâmetler, ilmî dayanaktan yoksundur. Bu tür yaklaşımlar, sadece zorlama te'villere dayandırılabilir ve bu manadaki kerâmet inancının menkıbelere bağlı bir kültten ibaret olduğu söylenebilir. Hz. Peygamber'in ve ashabın hayatı da bu hususu desteklemektedir. Bunun yanında sahabenin kerametlerinin işlendiği eserlerde dualarının kabul olunduğuna ilişkin malumatın büyük bir yekûn tutması da bu görüşü destekler niteliktedir. ${ }^{85}$

\subsection{Kerâmet-Mûcize İlişkisi}

Kerâmet mûcize gibi tabiat kanunlarıyla açıklanamayan hârikulâde bir hadise olarak tanımlansa da bazı yönleriyle mûcizeden ayrılmaktadır. Kerâmet ve mûcize arasındaki benzerlik ve farklılıkları aşağıda maddeler halinde inceleyelim:

1) Mûcize peygamberden, kerâmet ise velî kullardan sâdır olur. İslâm şeriatına uygun bir şekilde gerçekleşen kerâmet, şeriata uymayan bir fâsıktan zuhur etmez. ${ }^{86}$

\footnotetext{
83 Bk. Kâdî Abdülcebbâr, Muğgn̂, 25/217-218, 225, 241-243; Şehristânî, el-Milel ve'n-Nihal, 1/84-85; Cüveynî, Kitâbü'l-İrşâd, 317; Nesefî, Tebsıra, 2/107-110; Râzî, Mefâtihu'l-Gayb, 8/38; Bulut, "Hârikulâde Olması Açısından Kerâmet ve Mûcize İle İlişkisi", 338-339.

${ }^{84}$ Bk. Yavuz, "İslam İnancında Kutsiyet, Velayet ve Kerâmet İnancına İtikadi Mezheplerin Bakışı”, 122.

${ }^{85}$ Bk. Yavuz, "Kerâmet", 25/269.

${ }^{86}$ Ebû Ya'lâ, Muhammed b. Hüseyin el-Ferra, el-Mu'temed fi Usûli'd-Dîn, neş. V. Zeydan Haddad (Beyrut: 1974), 161; ayrıca bk. Râzî, Kitâbu'l-Erbaîn, 2/205.
} 
2) Kerâmet ve mûcize tabiat kanunlarına aykırı bir şekilde gerçekleşir. ${ }^{87} \mathrm{Bu}$ noktada şöyle bir farklılık vardır: Mûcize tüm hârikulâde hadiseleri kapsar; kerâmet içinse böyle bir durum söz konusu değildir. ${ }^{88}$

3) Mûcize ve kerâmet Allah'ın fiilidir. Dolayısıyla mûcize gibi kerâmetin de sahibi ve yaratıcısı Allah'tır. Fakat mûcize, peygamberin herhangi bir ön hazırlığı olmaksızın gerçekleşir; kerâmet ise sâlih kimsenin ibadet ve taatlerinin neticesinde vuku bulur denebilir. ${ }^{89}$

4) Kerâmetin ancak şeriatın emirlerine tâbi olan velî kulların elinde zuhur edebileceği kabul edilmiştir. Bu husus peygambere bağllığın bir karşıllı̆ı gibi de telakki edilmiştir. Bunun yanında kerâmetler, velî kulun bağlı olduğu peygamberin bir mûcizesi olarak da değerlendirilmiştir. Ayrıca görüşlerinde doğru olmayan kimsenin velî olamayacağı ve bu doğrultuda velî kimsenin görüşlerinin ilâhi buyruklara uygun olması gerektiği belirtilmiştir.90

5) Mûcizede bir benzerinin meydana getirilmesi konusunda tehaddî ve peygamberlik iddiası söz konusudur. Kerâmette ise tehaddî, velayet veya herhangi bir şeyi ispat söz konusu değildir. ${ }^{91}$

6) Peygamberin, risâlet vazifesinin ispatı için mûcize ortaya koyması gerekir ve o, ortaya koyduğu hadisenin de mûcize olduğunun bilincindedir. Kerâmette ise böyle bir durum söz konusu değildir. Hatta birçok âlime göre kerâmet, velî kimsenin isteği dışında gerçekleşir ve velî kimsenin bu durumu gizlemesi gerekir. Ayrıca velî, kerâmet iddiasında bulunmaz ve kendisinde izhar eden hallerin kerâmet olduğunu da dillendirmez. Hatta velî kimse, kerâmetin Müslümanlardan bir başkasına ait olduğunu ifade eder. ${ }^{92}$

7) Aklî düzlemden hareketle gerek mûcize gerekse de kerâmet mümkündür. ${ }^{93}$

8) Mûcize, peygamberin risâletle tavzif edilmesinden sonra vuku bulur. Kerâmette ise bir görevlendirme söz konusu değildir. Kerâmet, velayet mertebesine ulaşan her sâlih kimseden sâdır olabilir. Bunun yanında peygamber risâlet görevi sebebiyle ismet sıfatıyla muttasıftır; velî kimse için böyle bir durum söz konusu değildir. ${ }^{94}$

9) Mûcize nübüvvetin ispatı ve bilinmesi için elzemdir; bu bağlamda peygamberin elinde zuhur eden mûcize, onun doğruluğunu da ispat eder. Allah'ın emir ve yasaklarına büyük bir titizlikle riayet eden velî kulun elinde meydana gelen kerâmetin de onun doğruluğuna delil teşkil ettiği iddia edilmişse de bu yaklaşım doğru değildir. Nitekim o, söz konusu kerâmeti gizler, dillendirmez, insanların bu kerâmete inanmasını da talep etmez. ${ }^{95}$

10) Mûcize herkese açık olduğu için bütün insanlar tarafından müşahede edilebilir. Kerâmette ise durum farklıdır, kerâmeti fâsıklar göremez.

\subsection{Doğruluk Kıstası Bă̆lamında Kerâmet}

\footnotetext{
${ }^{87}$ Tahâvî, Şerhu Akîdedi't-Tahâviyye (Riyad, 1412), 507; Bağdâdî, el-Fark beyne'l-Fırak, neş. M. Muhyiddin Abdülhamid (Beyrut, 1990), 174.

${ }^{88}$ Bâkillânî, Kitâbü'l-Beyân 'ani'l-Fark beyne'l-Mu 'cizât ve'l-Kerâmât, neş. Richard Mccarthy (Beyrut, 1958), 5.

${ }^{89}$ Bk. Rağıb el-İsfahânî, el-i'tikââât, 129.

${ }^{90}$ Bk. Sâbûnî, el-Bidâye, 113.

${ }^{91}$ Bağdâdî, Usûlu'd-Dîn, 174-175; Nesefî, Tebsıra, 2/108; Râzî, Kitâbu'l-Erbaîn, 2/205; Kuşeyrî, Risaletü'l-Kuşeyrîyye, s. 379;

bk. Yavuz, "Kerâmet", 268.

92 Nesefî, Tebsıra, 2/107; Teftâzânî, Şerhu'l-Mekâsıd, 5/73.

${ }^{93}$ Bağdâdî, Usûlu'd-Dîn, 174; Cüveynî, Kitâbü'l-İrşâd, 320.

${ }^{94}$ Bağdâdî, Usûlu'd-Dîn, 174; Teftâzânî, Şerhu'l-Mekâsıd, 5/77-78; bk. Bulut, "Hârikulâde Olması Açısından Kerâmet ve Mûcize İle İlişkisi", 347.

${ }^{95}$ Nesefî, Tebsira, 2/109.
} 
Ehl-i Sünnet kelâmcılarının çoğunluğuna göre sâlih bir kulun elinde zuhur eden kerâmet, söz konusu kimsenin velayet rütbesine ulaşttğını ve bu sebeple de ona değer verilmesi gerektiğini ifade eder. ${ }^{96}$ Bazı âlimler ise sâlih kimsenin elinde zuhur eden kerâmetin, onun tabi olduğu peygamberin doğruluğuna delil teşkil ettiğini savunmuştur. ${ }^{97}$ Bu bağlamda Teftâzânî (ö. 792/1390) şunları ifade eder: Velî kimseden zuhur eden hârikulâde hadiseler, onun bağlı bulunduğu ümmetin peygamberine ait bir mûcize olarak kabul edilir. Çünkü kerâmet sayesinde o şahsın velî olduğu bilinir. Bir kimse dindarlığında hak üzere ve dine bağlılığında samimi ve sadık olmazsa velî olamaz. ${ }^{98}$ Birtakım tasavvufî eserlerde ise peygamberlere verilen bazı mûcizelerin benzerlerinin, velîlere de verildiği iddia edilmiştir. Bu noktada velî kimsenin elinde zuhur eden kerâmetin onun doğruluğuna delil teşkil edip etmediği hususunun açıklığa kavuşturulması gerekmektedir.

Esasında tasavvufî kaynaklarda kişinin doğru olmasına kerâmet sahibi olmasından daha fazla önem atfedilmiştir. ${ }^{99}$ Söz konusu kaynaklarda kerâmet, doğruluk kıstası olarak da görülmüştür. Buna göre kerâmet, velî kimsenin doğru olduğunu ortaya koymakta, dolayısıyla da yalancı bir kimsenin elinde zuhur etmemektedir. ${ }^{100}$ Fakat kerâmetin kişinin korunmuşluğuna veya doğruluğuna delil teşkil ettiği iddiası nasslarla bağdaşmamaktadır. Diğer taraftan bazı Sünnî âlimler de kerâmeti, velî kimsenin doğruluğu ile ilişkilendirmişlerdir. ${ }^{101}$ Ayrıca kerâmetin vukuu, kerâmet gösteren kimsenin velî olduğunun delili olarak da ele alınmıştır. Kişinin velî olmasının da zühd ve takva ehli, İslâm'ın esaslarına tam olarak bağlı olan birisi olduğunu ortaya koyduğu iddia edilmiştir. ${ }^{102}$ Fakat bu noktada bir tenakuz göze çarpmaktadır. Zira bir kimse, velî ise görüş ve davranışlarında da doğru olduğu söylenebilir. Ama kişinin doğru yolda olduğu biliniyorsa kerâmetin onun doğruluğuna delil olmasının bir anlamı olmaz. Bu durumda kerâmeti, doğruluk kıstası olarak ele almak yerine Allah'ın mümin kullarını desteklemek ve sıkıntıda/darda olanlara yardım etmek üzere mümin kullara bahşettiği bir ikram olarak kabul etmek daha isabetli görünmektedir. ${ }^{103}$

Kâdî Abdülcebbâr'a göre mûcize, bi'setten sonra zuhur eder ve peygamberin doğruluğuna ve saygınlığına delil teşkil eder. Mûcize dişındaki olağanüstü hadiseler ise kişinin ne yüceliğine ne doğruluğuna ne de nübüvvetine delildir. Diğer bir ifadeyle elinde olağanüstü hadisenin zuhur ettiği kimse, daha önceden nübüvvet iddiasında bulunmamışsa, bu olağanüstü hadise söz konusu kimsenin nübüvvetine delil teşkil etmez. Mûcize dışındaki olağanüstü hadiseler eğer kişinin doğruluğuna ve yüceliğine delil kabul edilirse bu durumda yalancının elinde zuhur eden olağanüstü hadiselerin açıklanması mümkün olmayacaktır. Nitekim Hallâc-ı Mansûr'a da bazı hârikulâde hadiseler atfedilmiştir. Fakat söz konusu hadiseler çeşitli hilelere dayanmakta

\footnotetext{
96 Ömer Nasuhi Bilmen, Muvazzah İlm-i Kelam (İstanbul, 1339), 190.

97 Teftâzânî, Şerhu'l-Akâid, 316; Hücvîrî, Keşfu'l-Mahcîb, neş. Süleyman Uludağ (İstanbul: Dergah Yayınları, 1982), 336338.

98 Teftâzânî, Şerhu'l-Akâid, 316.

${ }^{99}$ Kuşeyrî, er-Risale, ter. Süleyman Uludă̆ (İstanbul: Dergah Yayınları, 1999), 228.

${ }^{100}$ Hücvîrî, Keşfü'l-Mahcûb, 2/453; bk. S. Sabri Yavuz, “Ehl-i Sünnet ve Mutezile Bağlamında Doğruluk Ölçüsü Olarak Kerâmet”, Kelam Araştırmaları Dergisi 3/1 (2005): 101; Hasan Türkmen, “Nübüvvetin İspatı Bağlamında Zemahşerî'nin Nübüvvete Bakışı", Dinbilimleri Akademik Araştırma Dergisi 18/2 (2018): 172.

101 Şehristânî, Nihâyetülli̇kdâm, (London, 1934), 498; İbn Fürek, Mücerredu Malakati'ş-Şeyh Ebi'l-Hasan-el-Eş'arî (Beyrut, 1987), 176-177.

102 Bk. Nesefî, Tebsıra, 2/107-110.

${ }^{103}$ Bk. Yavuz, "Ehl-i Sünnet ve Mutezile Bağlamında Doğruluk Ölçüsü Olarak Kerâmet”, 114-116; Bağdâdî, Usûlu'd-Dîn, 174-175.
} 
olup insanları aldatmaya yöneliktir. ${ }^{104}$ Kısacası Kâdî Abdülcebbâr'a göre mûcize dışındaki bir hadise doğruluk ölçütü olarak kabul edilemez.

Esasında velî bir kul olmak için iman etmek ve takva sahibi olmak kâfidir. Hârikulâde hadiseler ortaya koymak ile velî olmak arasında bir ilişki kurulması isabetli değildir. Zira kevnî kerâmet olarak adlandırılan hârikulâde hadiseler, Müslüman olmayan kimselerden de sâdır olabilmektedir. Sözgelimi Hint fakirleri, bazı Budist rahipler olağanüstü olaylar ortaya koyabilmektedir ve ortaya konulan bu hadiseler de birçok insanı etkilemektedir. Söz konusu hadiseleri ortaya koyan kimselerin, Allah nezdinde velî bir kul olduğu ise söylenemez. Aslında zikredilen şahıslar, belirli bir eğitim ve nefis terbiyesinden geçtikleri için söz konusu hadiseleri ortaya koyabilmektedirler. Keza kerâmet gösterdiği iddia edilen kimselerin yaşamlarına bakıldığı zaman onların az yemek yedikleri, az uyudukları, insanlardan uzaklaşıp inzivaya çekildikleri görülecektir. Bu durumda onların olağanüstü bazı hadiseler göstermeleri gayet tabiidir. Aslında olağanüstü hadiselerden hareketle kişilerin dinî konumunu değil, insanların dinî konumuna göre olağanüstü hadiseleri adlandırma yoluna gidilmiştir. Sözgelimi hârikulâde olay, inkârcı bir kimseden zuhur etmişse bu hadise onun dinî konumundan ötürü "istidrac" veya "ihanet" olarak isimlendirilmişken; mümin bir kuldan sâdır olmuşsa "maûnet"; sâlih bir kuldan sâdır olmuşsa söz konusu hadiseye kerâmet denilmiştir. Aynı hadise peygamberlik iddiası ve meydan okumayla birlikte vuku bulmuşsa mûcize olarak adlandırılmıştır. Peygamberlerin özel durumundan ötürü onları dışarda tutacak olursak, hârikulâde fiillerden hareketle bir kimsenin dinî konumunu belirlemek isabetli olmayacaktır. Bazen insanların söz, davranış ve hareketlerinden hareketle dinî konumlarına ilişkin tahminlerde bulunulabilir. Fakat velî olmak için hârikulâde hadiseler bir kıstas kabul edilemez. Kişi hârikulâde hadiseler ortaya koymadan da Allah dostu olabilir. Hâsılı hârikulâde bir hadiseyi ortaya koyduğu için kişinin velî addedilmesi veyahut olağanüstü bir hadise ortaya koyamadığı için kişinin velî olarak görülmemesi doğru bir yaklaşım değildir. ${ }^{105}$

Öte yandan kerâmet olduğu iddia edilen hadiselerin, bir şeyin hak oluşunun veya doğruluğun delili gibi görülmesi, isabetli bir yaklaşım değildir. Gizliyi de açık olanı da bilen sadece Allah olduğu için kimin gerçekten velî olduğunu da sadece Allah bilebilir. Dolayısıyla bu konuda insanların yapacağı bir belirleme/tanımlama doğru bir sonuç vermeyecektir. İnsanlara Allah'a olan itaatlerinden ötürü kıymet verilebilir; fakat onların kutsanıp yüceltilmesi ve peygambere özgü özel bazı vasıfları haiz olduklarının söylenmesi doğru değildir. Netice olarak velî bir kimsenin olağanüstü bir hadise ortaya koyması, onun doğruluğuna delil teşkil etmez ve de hârikulâde hadiseler insanların Allah katındaki derecelerinin/konumlarının belirlenme kriteri olamaz. ${ }^{106}$

\section{Sonuç}

Klasik kelâm ilminde mûcize, nübüvveti ispat eden bir delil olarak kabul edilir. Kerâmet ise peygamber dışındaki velî kimselere nispet edilen hârikulâde olaydır. Ancak iki terim arasındaki farklar peygamber ve velî arasındaki farklar kadar açıktır. İslâm âlimleri ağırlıklı olarak her iki

\footnotetext{
${ }^{104}$ Kâdî Abdülcebbâr, Muğnî, 15/226-227, 242.

105 Bk. Teftâzânî, Şerhu'l-Akâid, 314-318; İbnü'l-Cevzi, Telbisu İblis, neş. Münîr ed-Dımaşkî (Kahire, 1368), 378; Beyazîâade Ahmed Efendi, İmam-ı Azam Ebû Hanîfe'nin İtikadî Görüşleri, çev. İlyas Çelebi (İstanbul: İFAV, 2017), 119; geniş bilgi için bk. Bulut, "Hârikulâde Olması Açısından Kerâmet ve Mûcize İle İlişkisi”, 344-346.

${ }^{106}$ Metin Özdemir, "İslam Akâidinde Kutsiyet, Velâyet ve Kerâmet İnancına İtikadî Mezheplerin Bakışı Başlıklı Tebliğin Müzakeresi", İslam Düşünce ve Geleneğinde Kutsiyet Velâyet Kerâmet, ed. Yusuf Şevki Yavuz (İstanbul: Kuramer Yayınları, 2017), 158.
} 
hârikulâde hadiseyi hak kabul etmiş; fakat ikisinin arasındaki farkları da ortaya koymayı ihmal etmemişlerdir. Bu bağlamda mûcize, nübüvvetin delili; kerâmet ise genellikle evliyanın taltifi olarak değerlendirilmiştir. Allah'ın elçilerini teyit etmek üzere yarattığı -hissî- mûcize, tabiat kanunlarının bir süreliğine askıya alınması şeklinde vuku bulur. Böylece nübüvvet ispat edilmiş olur. Velî kimsenin elinde, peygambere verilen -hissî- mûcizenin bir benzerinin (tabiat kanunlarını aşan ve velînin tabiat üzerinde tasarruf etmesine dayandırılan hârikulâde hadiselerin) zuhur etmesi ise söz konusu değildir. Böyle bir kabulün ilmî bir temele dayandırılması da mümkün değildir.

Mu'tezile mûcizenin temel işlevinin nübüvvetin ispatına yönelik olduğunu kabul etmiş; bu doğrultuda -bazı istisnalar olmakla beraber- peygamber dışındaki kimselere hârikulâde bir hadisenin verilmediğini savunmuş ve aksi bir iddianın ise nübüvvet müessesesini zedeleyeceğini belirtmiştir. Ehl-i Sünnet de mûcizenin peygambere özgü olduğunu vurgulamış; ancak çoğunluk kerâmetin gerçekliğini kabul ederek bazı naklî delillere atıf yapmıştır.

Mûcize ve kerâmet gibi tabiatta gerçekleşen iki tabiatüstü olayın kabulü, âlem ve Tanrı ilişkisini "yaratan-yaratılan" şeklinde kabul etmekle mümkündür, denilebilir. Nitekim tüm âlemin Allah tarafından yaratıldığı ve belirli kanunlarla donatıldığı (âdetulah-fıtratullahsünnetullah) kabul edildiğinde yaratıcının âleme müdahalesi de mümkün olur. İslâm geleneğinde kabul görmüş olan muhdes, mahlûk ve mümkin âlem anlayışı, İslâm âlimlerini "âlemde her an ilâhi müdahalenin mümkün olduğu" sonucuna götürmüştür. Mûcize ve kerâmetin imkânını bu hakikate pekâlâ dayandırabiliriz.

Velî bir kimsenin, peygambere ait mûcizenin bir benzerini (tabiat kanunlarını aşan ve velînin tabiat üzerinde tasarruf etmesine dayandırılan bir hadiseyi) ortaya koyduğunun iddia edilmesi, nassların yanlış yorumlanmasından kaynaklanmaktadır. Kur'an'da mûcize dışında zikredilen hârikulâde hadiseler, kerâmet olarak açıklanabilir. Kerâmet nasslardan ve aklî düzlemden hareketle de izah edilebilir. Nitekim Allah her şeye gücü yetendir. O, dilerse kulunun elinde olağanüstü bir hadise yaratabilir. Bu düşünceyle velî kulun elinde kerâmetin zuhur ettiği söylenebilir. Fakat bu husus(da) -âhâd haberlere dayanıldığı için- kabulü zorunlu olan bir iman esası gibi görülmemelidir. Diğer taraftan kerâmete ilişkin deliller incelendiğinde, kerâmetin ağırlıklı olarak sıkıntı/darlık esnasında vuku bulduğu ve Allah'ın bir ikram ve lütfu olarak sıkıntıyı gidermeye yönelik olduğu görülmektedir. Fakat bazı şahısların farklı söylemlerle din kisvesi altında kendisinin üstün meziyetleri olduğunu belirtmesi veya mûcize benzeri hârikulâde hadiseler ortaya koyduğunu söylemesi, bu doğrultuda da sorgulanamaz ve mutlak bir otorite gibi görülmeleri aklî ve naklî açıdan izahı mümkün değildir; istismara açık olan bu hususta çok dikkatli olunmalıdır. Şu husus da bilinmelidir ki peygamber dışında hiç kimse masum değildir. Dolayısıyla bazı şahısların aşırı yüceltilmesi, onların yanılmaz kabul edilmesi ve peygambere özgü bazı özel sıfatlarla donatılması birçok sorunu da beraberinde getirecektir. ${ }^{107}$

İslâm'ın erken döneminde mûcizevî beklentiler ve isteklerin günümüzdeki boyutlarda olduğu söylenemez. Hz. Muhammed (sav) son derece sade, anlaşılır ve makul bir tebyin ve tebliğde bulunmuştur. Ne var ki ilerleyen dönemlerde çeşitli nedenlerle kimi zaman din aslından uzaklaştırılarak neredeyse mitolojik anlatılar ve kişiler ihdas edilmiştir. Bu bağlamda dinî söylem akılcı çizgiden uzaklaşarak toplumda kerâmeti kendinden menkul efsanevî karakterler söz sahibi kılınmıştır/olmuştur. İslâm'ı aklın sınırlarını zorlayacak şeylerle

107 Bk. Tevbe $9 / 31$. 
ilişkilendirmek, şüphesiz bu dine zarar verecektir. Bu nedenle mûcizenin peygamberlerle sınırlı olduğu, kerâmetin ise Allah'ın mümin kullarına bir hediyesi/ikramı ve yardımı olduğu kabul edilmelidir. Her dinî kisveye bürünen kişiye olağanüstü haller nispet etmenin ve İslâm'ın hakikatini Bâtınî yorumlarda aramanın İslâm'a sadece zarar vereceği akıldan çıkarılmamalıdır.

Öte yandan kerâmet, velî kimsenin doğruluğunun tespiti için bir kıstas değildir. Zira velî kimsenin kendi durumunu ortaya koymak gibi bir yükümlülügü de yoktur. İnsanların söz ve davranışlarına bakılarak bazı hükümler verilse dahi bu hüküm zanna dayandığı için her zaman doğru sonuç vermeyebilir. Bu sebeple birtakım şahısların velî olarak tayin veya ilan edilmesi doğru değildir; bu husus sadece bütün amellerin karşılığını tastamam verecek olan, kimin ne olacağını ve kalplerde gizli olanı bilen Allah'ın ilmi dâhilindedir. ${ }^{108}$ Şu halde bazı şahıslara söz, davranış, inanç ve yaşamlarından ötürü değer verilebilir ama onların kutsanıp aşırı derecede yüceltilmesi ve bu doğrultuda tam bir teslimiyetle onlara bağlanılıp her söz ve fiillerinin sorgulanmadan onaylanması kabul edilebilir bir yaklaşım değildir. Nitekim Allah'tan başka bir varlığa kutsiyet atfetmek nasslarla da bağdaşmaz. Bu husus gerek peygamberlerin mesajlarının temel prensibi olan tevhid gerekse de insanın selim fıtratına aykırıdır. Her çeşit noksanlıktan uzak ve her türlü övgü ve yüceltmeye layık olan yegâne varlık Allah'tır. Tevhid esası gereği sadece Allah'a güvenmeli, yönelmeli, sığınmalı ve O'ndan istemelidir.

\section{Kaynakça}

Abdülbâkî, M. F. el-Mu'cemu'l-Mufehres li elfâzi'l-Kur'ani'l-Kerîm. Kâhire: Dâru'l-Hadîs, 2007.

Ahmed b. Hanbel. el-Akîde. tah. A. İzzeddin es-Seyrevan. Dimeşk, 1408.

Ahmed b. Hanbel. Kitâbu'z-Zühd. tah. M. Celal Şeref. İskenderiyye: 1984.

Ali el-Kârî. Şerhu Kitabi'l-Fikhi'l-Ekber. Beyrut, 1984.

Âmidî, Seyfuddîn. Gâyetu'l-Merâm fi İlmi'l-Kelâm. tah. Hasan Mahmud Abdüllatif. Kahire, 1971.

Aydın, Hayati. "İslâm İnançları Açısından Mûcize, Kerâmet, Sihir ve İstidrac Kavramları Üzerine Bir Değerlendirme". S.Ü İlahiyat Fakültesi Dergisi, 17/32 (2015): 105-137.

Bağdâdî. Ebû Mansûr Abdülkahir b. Tâhir b. Muhammed et-Temîmî. el-Fark beyne'l-Fırak. neş. M. Muhyiddin Abdülhamid. Beyrut, 1990.

Bağdâdî. Ebû Mansûr Abdülkahir b. Tâhir b. Muhammed et-Temîmî. Usûlu'd-Dîn. İstanbul: Matbaatü'd-Devle, 1928.

Bâkıllânî, Ebû Bekr Muhammed b. et-Tayyib. Kitâbü'l-Beyân 'ani'l-Fark beyne'l-Mu 'cizât ve'lKerâmât. neş. Richard Mccarthy. Beyrut, 1958.

Bebek, Adil. "Kelam Literatürü Işığında Mûcize ve Hz. Muhammed'e Nispet Edilen Hissî Mûcizelerin Değerlendirilmesi”. M.Ü. İlahiyat Fakültesi Dergisi 18 (2000): 121-148.

Bekir Topaloğlu\&İlyas Çelebi. Kelâm Terimleri Sözlüğü. İstanbul: İsam Yayınları, 2013.

Beyazîzâde Ahmed Efendi, İmam-ı Azam Ebû Hanîfe'nin İtikadî Görüşleri. çev. İlyas Çelebi. İstanbul: İFAV, 2017.

Beyâzîzâde Ahmed Efendi. İ̧̧ârâtü'l-Meram. neş. Yusuf Abdürrezzak. Kahire: Mektebetü’lHalebî, 1368.

Bilmen, Ömer Nasuhi. Muvazzah İlm-i Kelam. İstanbul, 1339.

108 Fâtır 35/38; bk. Âl-i İmrân 3/115; Tevbe 9/44. 
Bulut, H. İbrahim. "Hârikulâde Olması Açısından Kerâmet ve Mûcize İle İlişkisi", S.Ü. İlahiyat Fakültesi Dergisi 3 (2001): 329-350.

Bulut, Halil İbrahim, "Sünnî Gelenekte Mûcize Kavramı ve Hz. Sâlih'in Deve Mûcizesi", Dinbilimleri Akademik Araştırma Dergisi 4/3 (2004): 137-150.

Bulut, H. İbrahim. "Mûcize". Türkiye Diyanet Vakfı İslâm Ansiklopedisi. İstanbul: TDV Yayınlar1, 2005, 30/350-352.

Bulut, H. İbrahim. Nübüvvetin İspatında Mûcize. Ankara: Araştırma Yayınları, 2016.

Cürcânî, Seyyid Şerîf. Şerhu'l-Mevâkıf. neş. Mahmut Ömer Dimyatî. Beyrut, 1998.

Cüveynî, İmâmu'l-Harameyn Ebî'l-Meâlî Abdilmelik. Kitâbü'l-İrşâd. tah. M. Yusuf MusaAbdulmun'im Abdulhamid. Misir, 1950.

Ebû Ya'lâ, Muhammed b. Hüseyin el-Ferra. el-Mu'temed fi Usûli'd-Dîn. neş. V. Zeydan Haddad. Beyrut, 1974.

Gazzâlî, Ebû Hamîd, el-ìktisâd fi'l-I'tikâd. Beyrut: Daru'l-Kütübi'l-İlmiyye, 1983.

Hakîm et-Tirmizî. Nevâdiru'l-Usul. tah. M. Abdülkadir Ata. Beyrut, 1992.

Hamidullah, Muhammed. "Mûcize, Kerâmet, İstidrac". ter. Zahit Aksu. Hikmet Yurdu 3 (2009): 81-93.

Hâris el-Muhâsibî. Risaletü'l-Müsterşidin. neş. Abdülfettah Ebu Gudde. Halep: 1964.

Harpûtî, Abdullatif. Tenkîhu'l-Kelam fi-Akâid-i Ehli'l-İslâm. çev. İ. Özdemir-F. Karaman. Elazığ: TDV Yayınları, 2000.

Hücvîrî, Ebü'l-Hasen Alî b. Osmân b. Ebî Alî el-Cüllâbî. Keşfu'l-Mahcûb. neş. Süleyman Uludağ. İstanbul: Dergah Yayınları, 1982.

İbn Fürek, Mücerredu Malakati'ş-Şeyh Ebi'l-Hasan-el-Eş'arî. Beyrut, 1987.

İbn Hazm. el-Fisal fi'l-Milel ve'l-Ehva ve'n-Nihal. Beyrut: 1317.

İbnü'1-Cevzi. Telbisu İblis. neş. Münîr ed-Dımaşkî. Kahire, 1368.

Kâdî Abdülcebbâr, el-Muğnî fì Ebvâbi't-Tevhîd ve'l-Adl. Kahire: 1962-65.

Kâdî Abdülcebbâr, Şerhu'l-Usuli'l-Hamse. tah. Abdülkerim Osman. Kahire: 1996.

Kâdî Abdülcebbâr, Tesbîtü Delâili'n-Nübüvve. tah. Abdülkerim Osman. Beyrut, tsz.

Kuşeyrî, Ebu'l-Kasım Abdülkerim b. Revazin. er-Risâletü'l-Kuşeyrîyye. Beyrut, 2001.

Maraz, Hüseyin. "Mûcizenin Teolojik Açıdan Delil Oluşu ve İlahi Yasalarla İlişkisi”, İ.Ü. Ilahiyat Fakültesi Dergisi 8/2 (2017): 292-317.

Nesefî, Ebû'l-Mu'în. Tebsıratü'l-Edille fì Usûli'd-Dîn. tah. Hüseyin Atay-Ş. Ali Düzgün. Ankara: D.İ.B. Yay., 2004.

Özdemir, Metin. “İslâm Akâidinde Kutsiyet, Velâyet ve Kerâmet İnancına İtikadî Mezheplerin Bakışı Başlıklı Tebliğin Müzakeresi". İslâm Düşünce ve Geleneğinde Kutsiyet Velâyet Kerâmet. ed. Yusuf Şevki Yavuz. İstanbul: Kuramer Yayınları, 2017, 153-160.

Râgib el-İsfahânî. el-ít'tikâdât. Beyrut: 1988.

Râzî, Fahruddîn. el-Muhassal. çev. Hüseyin Atay. Ankara: Ankara Üniversitesi İlahiyat Fakültesi Yayınları: tsz.

Râzî, Fahruddîn. Kitâbu'l-Erbaîn. neş. A. Hicâzî es-Sekâ. Kahire: Mektebetü'l-Ezher, 1986.

Râzî, Fahruddîn. Mefâtihu'l-Gayb. Beyrut: Daru'l-Kütübi'l-İlmiyye, 2000. 
Sâbık, Seyyid. Akâidü'l-İslâmiyye. Beyrut 1406.

Sâbûnî, Nûreddîn. el-Bidâye fì Usûli'd-Dîn. ter. Bekir Topaloğlu. İstanbul: İFAV, 2018.

Serdar, Murat. "Ehl-i Sünnet İnancında Kerâmetin İmkân ve Vukû'u Problemi". Bilimname 14/2 (2010): 25-46.

Şehristânî. el-Milel ve'n-Nihal. neş. M. Seyyid Kilânî. Beyrut, 1986.

Şehristânî. Nihâyetü'l-İkdâm fi İlmi'l-Kelâm. London, 1934.

Teftâzânî, Sa'duddîn. Şerhu'l-Akâid. ter. Süleyman Uludağ. İstanbul: Dergah Yayınları, 1999.

Teftâzânî, Sa'duddîn. Şerhu'l-Makâsıd. tah. Abdurrahman Umeyre. Beyrut: 1989.

Türkmen, Hasan. “Nübüvvetin İspatı Bağlamında Zemahşerî'nin Nübüvvete Bakışı”. Dinbilimleri Akademik Araştırma Dergisi 18/2 (2018): 167-184.

Uludağ, Süleyman. "Kerâmet". Türkiye Diyanet Vakfi İslâm Ansiklopedisi. Ankara: TDV Yayınlar1, 2002. 25/265-268.

Vecdî, Ferîd. el-İslâm fi Asri'l-ïlm. Kahire, 1932.

Yavuz, Sâlih Sabri. “Ehl-i Sünnet ve Mutezile Bağlamında Doğruluk Ölçüsü Olarak Kerâmet". Kelam Araştırmaları Dergisi 3/1 (2005): 91-116.

Yavuz, Yusuf Şevki. "İslâm İnancında Kutsiyet, Velayet ve Kerâmet İnancına İtikadi Mezheplerin Bakışı". İslâm Düşünce Geleneğinde Kutsiyet Velayet Kerâmet. ed. Yusuf Şevki Yavuz. İstanbul: Kuramer Yayınları, 2017, 113-150.

Yavuz, Yusuf Şevki. "Kerâmet". Türkiye Diyanet Vakfı İslâm Ansiklopedisi. Ankara: TDV Yayınları, 2002, 25/268-270. 